J. Clin. Chem. Clin. Biochem.

Vol. 17, 1979, pp. 789-794

\title{
A Simple Method of Quantitative Estimation of the Subfractions of Human Serum Small Molecular Diameter Lipoproteins
}

\author{
By J. Janecki and Anna Fijalkowska
}

Institute of Pediatrics, Medical Academy, Warszawa, Poland

(Received September 22, 1978/June 8, 1979)

Summary: The method presented allows the separation and fractionation of up to 12 subfractions of human serum small molecular diameter lipoproteins (SMDL) by polyacrylamide gel electrophoresis. The method was checked and confirmed by more than 2000 separations. The frequency of the appearence of the particular subfractions was investigated in 300 persons - children and adults. The method of quantitative estimation of each subfraction was evaluated. The precision of this method was $3 \%$ to $11 \%$ (mean $6 \%$ ). A good reproducibility of separations was found within 2 to 4 days after blood collection (with refrigeration). The stability of the separation patterns was satisfactory for up to 9 days in five healthy persons. Examples of differences in the SMDL-subfraction patterns, depending on sex, age and pathology, are given.

\section{Eine einfache Methode zur quantitativen Bestimmung der Subfraktionen von Lipoproteinen geringen Molekuldurch-} messers (SMDL) im Serum vom Menschen

Zusammenfassung: Die vorgestellte Methode erlaubt die Trennung von Lipoproteinen geringen Moleküldurchmessers im Serum vom Menschen in bis zu zwölf Subfraktionen von unterschiedlicher elektrophoretischer Beweglichkeit in Polyacrylamidgel. Die.Methode wurde an mehr als 2000 Trennungen geprüft und bestätigt. Die Häufigkeit des Auftretens einzelner Subfraktionen wurde bei 300 Probanden - Erwachsenen und Kindern - untersucht. Die Methode der quantitativen Bestimmung jeder Subfraktion wurde geprüft. Die Präzision der Methode betrug 3-11\% $(\overline{\mathrm{x}}=6 \%)$. Eine gute Reproduzierbarkeit der Trennungen wurde innerhalb 2-4 Tagen nach Probennahme bei Probenverwahrung im Kühlschrank gefunden. Zufriedenstellende Stabilität der Trennbilder innerhalb neun Tagen wurde durch je fünf Untersuchungen von Gesunden bestätigt. Einige Beispiele für SMDL-Subfraktionen-Bilder bei verschiedenem Alter, Geschlecht.und Erkrankungen werden gegeben.

\section{Introduction}

Separation of HDL, $\alpha$-lipoproteins and small molecular diameter lipoproteins (SMDL) has been described by many authors $(1-8)$. Our study was aimed at finding a simple but quantitative, precise and reproducible method of differentiation of lipoproteins, which penetrate $75.0 \mathrm{~g} / \mathrm{l}$ polyacrylamide gel (SMDL), i.e. a method which would allow the observation of subfraction changes depending on sex, age or various pathologic stages.

\section{Materials and Methods}

More than 2000 sera were investigated. Blood was collected from the umbilical cord and from children of different ages, hospitalised in the Institute of Pediatrics at the Medical Academy in Warsaw, as well as from adults. The group of "healthy persons" were children following small accidents, such as foreign body in the ear or respiratory tract, children with epilepsy or psychopathy and healthy young adult persons (students of Technical High School in Warsaw).

We collected sera from various patients in order to observe the quantity and type of the SMDL subfractions from a wide range of diseases.

Blood samples were taken after overnight fasting; sera were used immediately or kept in a refrigerator for not more than 3 days.

Electrophoresis

Sera were prestained with Sudan Black B by the method of Ressler et al. (9) and separated in polyacrylamide gel according to the method of Wollenweber ct al. (10) modified by the authors.

The gel columns were made from Cyanogum 41 (Fischer USA) as follows:

Spacer gel - $27.5 \mathrm{~g} / 1$ Cyanogum in tris- $\mathrm{HCl}$ buffer $(60 \mathrm{ml} 1 \mathrm{~mol} / 1$ $\mathrm{HCl}+7.4 \mathrm{~g}$ tris per liter $=\mathrm{pH} 6.7$ ).

Separation gel I-34.0 g/l Cyanogum and separation gel II$75.0 \mathrm{~g} / \mathrm{l} \mathrm{Cyanogum} \mathrm{in} \mathrm{tris-} \mathrm{HCl}$ buffer $(60 \mathrm{ml} 1 \mathrm{~mol} / 1 \mathrm{HCl}+$ $33.0 \mathrm{~g}$ tris per liter $=\mathrm{pH} 8.9$ ). 
$1 \mu \mathrm{l}$ te trame thylenediamine (BDH) and $2 \mu \mathrm{l}$ of $100 \mathrm{~g} / 1$ solution of ammonium persulphate ( $\mathrm{POCH}$ ) were added per $1 \mathrm{ml}$ of Cyanogum solution immediately before use. The chromatographic columns were prepared in glass tubes of $7 \mathrm{~cm}$ length and $5 \mathrm{~mm}$ internal diameter. They were fixed vertically in special rubber stoppers. The electrophoresis was carried out not earlier than 24 hours after the gel had been made but not later than 4 days of storage at $+4^{\circ} \mathrm{C}$.

$40 \mu \mathrm{l}$ of a mixture containing serum, dye solution and $200 \mathrm{~g} / \mathrm{l}$ sucrose solution (volumes, $2+1+1$ ) was put on top of the column. A current of $2 \mathrm{~mA}$ per column was used. Electrophoresis was carried out with buffer pH $8.6(28.8 \mathrm{~g}$ gly cine + $0.6 \mathrm{~g}$ tris per liter) for about 2 hours until the albumin front was 5-7 $\mathrm{mm}$ from the lower end of the column.

\section{Documentation}

Immediately the electrophoresis was finished all results were registered by photography using both black-and-white negative film and colour positive film and by densitometry using the Modular Vitatron Photometer $(0.5 \mathrm{~mm}$ slit, $616 \mathrm{~nm}$ wave length).

\section{Results}

The electrophoretic run resulted in 2 coloured lipoprotein fractions: the first penetrated separation gel II and the second one stopped in separation gel I (fig. 1).

In the gel region between both groups no lipoproteins binding Sudan Black B were observed. A brown-gray fraction, which moved in front of the separation, was identified immunologically as albumin. The main SMDL group in separation gel II ran with a relative mobility of 0 to 0.5 towards the albumin. Between this group and albumin we always found a more or less intense subfraction with a relative mobility about 0.7 .

SMDL subfractions of lower mobility had a classical "disc" character, and those of higher mobility were more zonal (tab. 1).

The disc subfractions were generally easier to identify, especially subfractions $f_{3}$ and $f_{7}$. In a large number of separations of different sera it was possible to find some, in which the zonal subfractions were also distinct. Comparing the columns with densitograms just after separation, it was not difficult to identify zonal subfractions, when they were not very distinct (fig. 2).
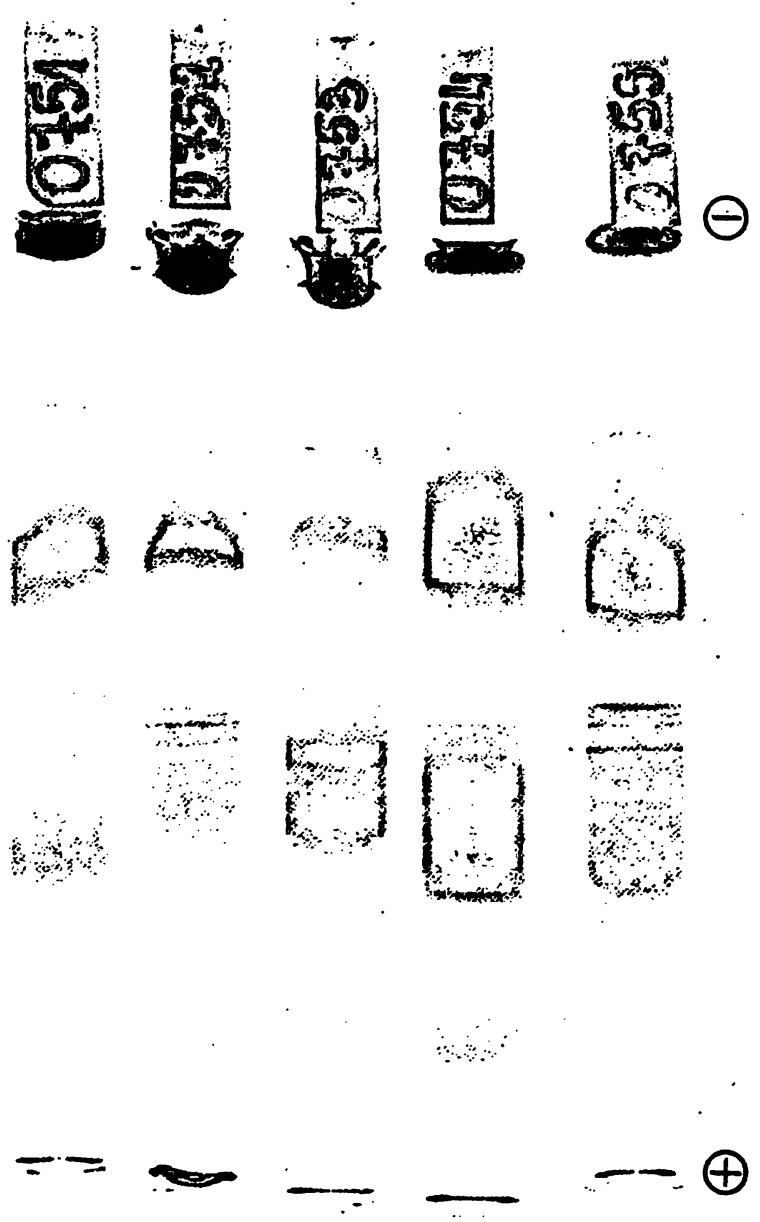

Fig. 1. A batch of columns showing SMDL-differentiation in serum from healthy people. Note the differences in intensity of the staining in different columns.

Not all subfractions were seen on every column. Some of them appeared very often, others rather rarely. Table 2 shows the frequency of the SMDL subfractions as found in the sera of 300 healthy persons.

Tab. 1. The electrophoretic mobility of SMDL subfractions toward albumin in separation gel II.

\begin{tabular}{|c|c|c|c|c|c|c|c|c|c|c|c|c|c|}
\hline $\begin{array}{l}\text { No of } \\
\text { subfraction }\end{array}$ & $f_{1}$ & $\mathrm{f}_{2}$ & $f_{3}$ & $f_{4}$ & $f_{5}$ & $f_{6}$ & $f_{7}$ & $\dot{f}_{8}$ & $f_{9}$ & $f_{10}$ & $\dot{f}_{11}$ & $f_{12}$ & Albumin \\
\hline \multicolumn{14}{|l|}{ Mobility } \\
\hline from & & 0.01 & 0.03 & & 0.10 & 0.14 & 0.22 & 0.25 & 0.32 & 0.38 & 0.44 & 0.64 & \\
\hline to & 0 & 0.03 & 0.07 & & 0.13 & 0.18 & 0.24 & 0.30 & 0.37 & 0.42 & 0.51 & 0.71 & 1.0 \\
\hline $\begin{array}{c}\text { Character } \\
\text { "disc" } \\
\text { zonal }\end{array}$ & + & + & + & + & + & $\begin{array}{l}+ \\
+\end{array}$ & + & + & + & + & $\begin{array}{l}+ \\
+\end{array}$ & + & . \\
\hline
\end{tabular}




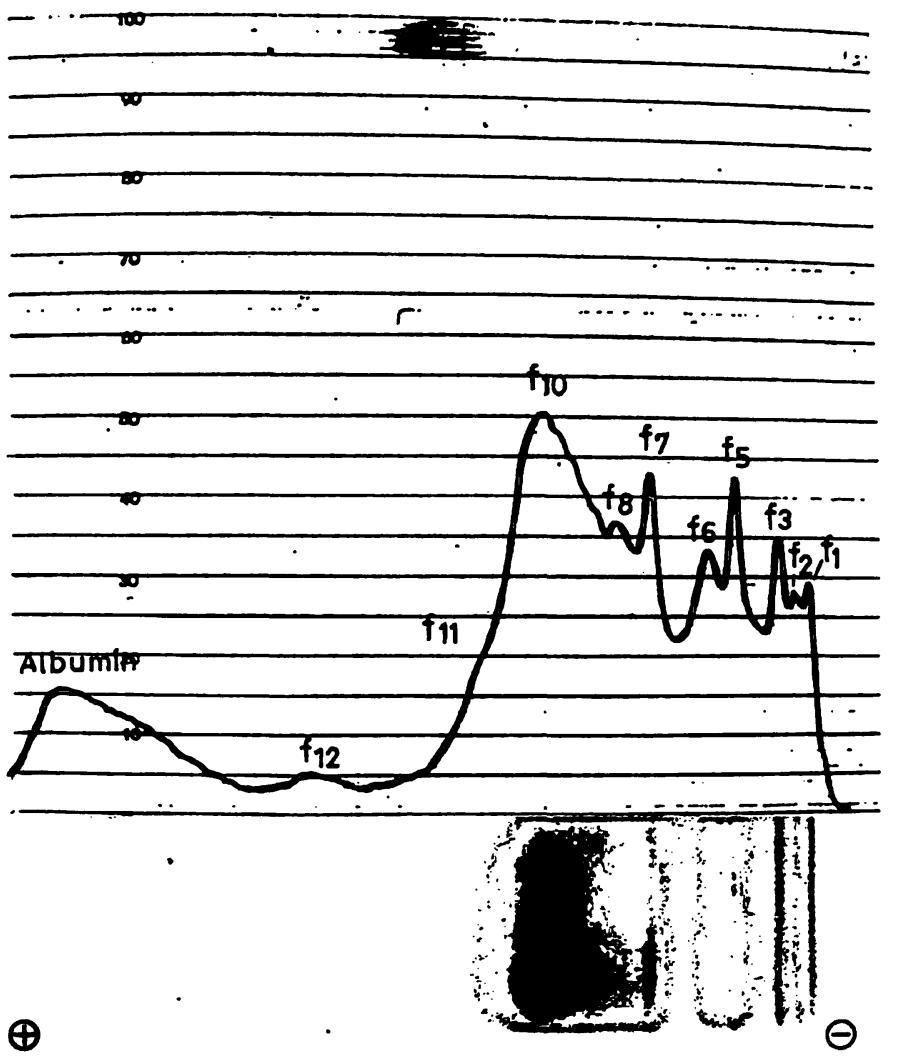

Fig. 2. Comparision of the column (separation gel II) with the corresponding densitogram. Note the differences of "disc" $\left(f_{1}, f_{2}, f_{3}, f_{5}, f_{7}\right)$ and zonal-fractions $\left(f_{6}, f_{8}, f_{10}\right.$, $\left.f_{11}, f_{12}, A l b.\right)$.

To evaluate the amount of each subfraction, the peaks of the densitometric curve were measured. A reproducible length of separation of SMDL was difficult to obtain. A correction of densitometrical readings was therefore sometimes used: galvanometer settings were multiplied by 100 , then divided by the length of the pathway of albumin in separation gel II (mostly $100 \mathrm{~mm}$ in the standard densitogram). This mathematical treatment gave a better comparison of results.

The precision of the quantitative estimation of the particular SMDL subfractions in the same serum was investigated in 9 columns (fig. 3). The variation coefficient varied from $3.3 \%$ to $11 \%$, mean $6.2 \%$ (tab. 3). To prove the reproducibility of the quantitative estimation of the subfractions, which reflects the stability of the material and methodical parameters, the electrophoresis of some sera, kept in the refrigerator at $+4{ }^{\circ} \mathrm{C}$, was carried out after 2 to 3 days, in separately prepared columns. The recorded values were $95 \%$ to $108 \%$, mean $101 \%$ of the initial values

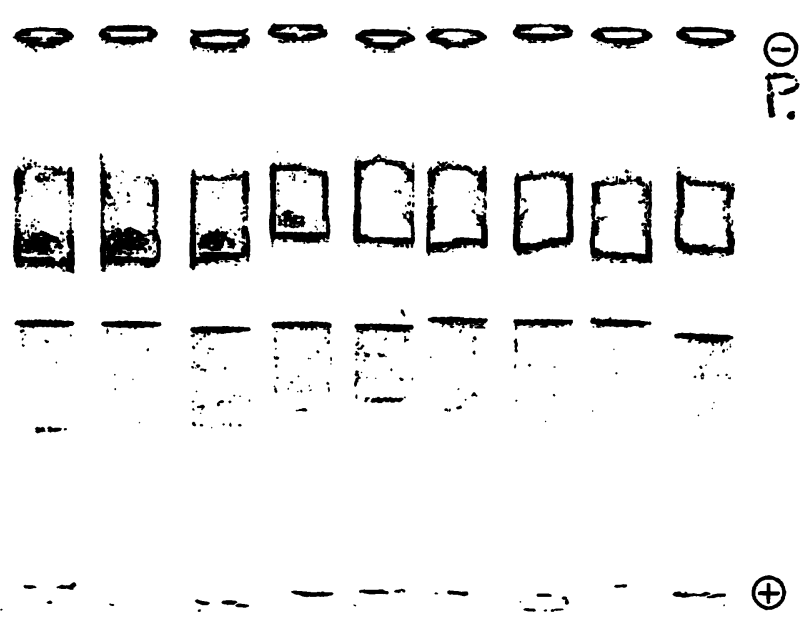

Fig. 3. Separation of the same serum in 9 parallel columns. Usually the differences in the length are smaller than in this batch (compare fig. 1 and 4 ).

(tab. 4). We did not therefore find any systematical loss or increase of the SMDL subfraction due to storage in the refrigerator for this short period.

The stability of the patterns of SMDL subfractions were proved in 4 healthy persons ( 1 man and 3 women). The blood was collected every second day for 9 days, the way of life and nutrition were normal. The mean deviation of particular subfractions was not higher than $15 \%$ of the mean value.

In the above described method the sera investigated were taken from healthy persons of different sex and age, especially children. In table 5 it is evident that some subfractions are mostly higher than others (e.g. subfractions $\left.f_{6}, f_{7}, f_{8}, f_{9}, f_{10}\right)$. It was also observed that some differences depend on sex and age, e.g. subfraction $f_{2}$ diminished generally with age especially in females, while subfraction $f_{7}$ increased rapidly in young women when compared with girls.

Changes of SMDL subfractions in different diseases were qualitative as well as quantitative. Generally, a decrease of all SMDL subfractions was observed in patients with a decreased HDL level in various diseases, e.g. severe neoplasma, nephropathy and liver failure. In other diseases we observed some changes in particular subfractions, e.g. $f_{6}$ and $f_{7}$ by some gynecologi$\mathrm{cal}$, endocrinological dysfunctions. The most impressive changes were found in cases of acute liver failure, e.g. acute viral hepatitis (fig. 4). Often during this disease all sub-

Tab. 2. The frequency (\%) of the appearence of SMDL subfractions in sera of healthy persons.

\begin{tabular}{llllllllllll}
$\begin{array}{l}\text { No of } \\
\text { subfraction }\end{array}$ & $f_{2}$ & $f_{3}$ & $f_{4}$ & $f_{5}$ & $f_{6}$ & $f_{7}$ & $f_{8}$ & $f_{9}$ & $f_{10}$ & $f_{11}$ & $f_{12}$ \\
\hline$\%$ & 83 & 96 & 8 & 95 & 80 & 96 & 76 & 65 & 87 & 95 & 100 \\
\hline
\end{tabular}


Tab. 3. Precision of subfractions (calculated as height of peaks on densitogram corrected for the length of separation)

\begin{tabular}{|c|c|c|c|c|c|c|c|}
\hline No of & Number & fraction & & & & & \\
\hline column & $f_{3}$ & $f_{5}$ & $f_{7}$ & $f_{8}$ & $f_{9}$ & $f_{11}$ & $f_{12}$ \\
\hline $\begin{array}{l}1 \\
2 \\
3 \\
4 \\
5 \\
6 \\
7 \\
8 \\
9\end{array}$ & $\begin{array}{r}103.5 \\
92.7 \\
88.2 \\
88.7 \\
97.6 \\
84.5 \\
84.1 \\
80.8 \\
79.8\end{array}$ & $\begin{array}{l}78.0 \\
82.2 \\
81.2 \\
85.0 \\
78.7 \\
80.6 \\
79.1 \\
70.9 \\
78.4\end{array}$ & $\begin{array}{l}85.5 \\
92.7 \\
91.0 \\
88.7 \\
87.1 \\
85.8 \\
84.1 \\
77.5 \\
82.6\end{array}$ & $\begin{array}{l}67.5 \\
70.0 \\
70.0 \\
67.5 \\
64.1 \\
68.9 \\
65.2 \\
66.0 \\
70.0\end{array}$ & $\begin{array}{l}79.5 \\
89.2 \\
88.2 \\
81.2 \\
87.1 \\
83.2 \\
78.3 \\
82.5 \\
81.2\end{array}$ & $\begin{array}{l}99.0 \\
85.7 \\
96.6 \\
72.5 \\
78.7 \\
81.9 \\
76.8 \\
79.2 \\
77.0\end{array}$ & $\begin{array}{l}37.5 \\
36.7 \\
37.8 \\
36.2 \\
34.6 \\
41.6 \\
34.8 \\
37.9 \\
36.4\end{array}$ \\
\hline $\begin{array}{l}\frac{\text { sum }}{\mathrm{x}} \\
\mathrm{s} \\
\mathrm{CV}\end{array}$ & $\begin{array}{c}799.9 \\
88.9 \\
7.86 \\
8.8\end{array}$ & $\begin{array}{c}714.7 \\
\cdot 79.4 \\
3.86 \\
4.9\end{array}$ & $\begin{array}{c}775.0 \\
86.1 \\
4.56 \\
5.3\end{array}$ & $\begin{array}{c}609.1 \\
67.7 \\
2.24 \\
3.3\end{array}$ & $\begin{array}{c}750.4 \\
83.4 \\
3.90 \\
4.7\end{array}$ & $\begin{array}{c}747.4 \\
83.1 \\
9.13 \\
11.0\end{array}$ & $\begin{array}{c}333.5 \\
37.1 \\
2.07 \\
5.6\end{array}$ \\
\hline
\end{tabular}

$\overline{\mathrm{CV}}=6.2$

Tab. 4. Reproducibility of subfractions investigated after 2-3 days (calculated as percent of first measurement).

\begin{tabular}{|c|c|c|c|c|c|c|c|c|c|}
\hline \multirow{2}{*}{$\begin{array}{l}\text { No of } \\
\text { serum }\end{array}$} & \multicolumn{4}{|c|}{ Number of subfraction } & \multicolumn{5}{|c|}{ 一 } \\
\hline & $f_{3}$ & $f_{5}$ & $f_{6}$ & $\mathrm{f}_{7}$ & $\mathrm{f}_{8}$ & $f_{9}$ & $f_{10}$ & $f_{11}$ & $f_{12}$ \\
\hline 0673 & 98 & 99 & 97 & 102 & 98 & 94 & 89 & 134 & 130 \\
\hline 0693 & 103 & 114 & 108 & 102 & 108 & 104 & 104 & 104 & 60 \\
\hline 0731 & 97 & 97 & 101 & 102 & 104 & 100 & 105 & 95 & 93 \\
\hline 0745 & 123 & 103 & 109 & 94 & 99 & 100 & 101 & 91 & 81 \\
\hline 0829 & 107 & 78 & 100 & 103 & 100 & 97 & 98 & 129 & 87 \\
\hline 0881 & 88 & 116 & 111 & 108 & 110 & 106 & 83 & 77 & 103 \\
\hline 1102 & 96 & 104 & 108 & 123 & 136 & 93 & 81 & 99 & 100 \\
\hline 1163 & 88 & 104 & 103 & 106 & 113 & 101 & 86 & 84 & 131 \\
\hline 1165 & 83 & 132 & 114 & 109 & 109 & 102 & 86 & 70 & 109 \\
\hline 1167 & 69 & 103 & 102 & 100 & 106 & 119 & 100 & 81 & 111 \\
\hline 1237 & 104 & 87 & 83 & 101 & 117 & 98 & . 95 & 120 & 89 \\
\hline 1314 & 97 & 81 & 92 & 90 & 96 & 112 & 110 & 101 & 129 \\
\hline sum & 1153 & 1218 & 1228 & 1240 & 1296 & 1226 & 1138 & 1185 & 1223 \\
\hline $\bar{x}$ & 96.1 & 101.5 & 102.3 & 108.0 & 102.2 & 94.8 & 94.8 & 98.8 & 101.9 \\
\hline$s$ & 13.5 & 15.1 & 8.7 & 8.2 & 10.9 & 7.4 & 9.6 & 20.3 & 21.7 \\
\hline
\end{tabular}

$\overline{\overline{\mathrm{x}}}=100.99$

Tab. 5. Patterns of SMDL subfractions in groups of different sex and age.

\begin{tabular}{|c|c|c|c|c|c|c|c|c|c|c|}
\hline \multirow[t]{2}{*}{ Age } & \multirow[t]{2}{*}{ Sex } & \multicolumn{9}{|c|}{ Number of subfraction } \\
\hline & & $\mathrm{f}_{2}$ & $\mathbf{f}_{3}$ & $f_{5}$ & $\mathrm{f}_{6}$ & $\mathrm{f}_{7}$ & $\mathrm{f}_{8}$ & $f_{9}$ & $f_{10}$ & $f_{11}$ \\
\hline Babies & $\begin{array}{l}q \\
0\end{array}$ & $\begin{array}{l}31.8 \\
25.8\end{array}$ & $\begin{array}{l}44.5 \\
35.8\end{array}$ & $\begin{array}{l}60.0 \\
43.9\end{array}$ & $\begin{array}{l}52.5 \\
42.0\end{array}$ & $\begin{array}{l}55.5 \\
46.0\end{array}$ & $\begin{array}{l}58.6 \\
48.7\end{array}$ & $\begin{array}{l}58.6 \\
54.4\end{array}$ & $\begin{array}{l}55.5 \\
50.0\end{array}$ & $\begin{array}{l}41.7 \\
32.6\end{array}$ \\
\hline $3-10$ years old & $\begin{array}{l}9 \\
0\end{array}$ & $\begin{array}{l}24.4 \\
24.5\end{array}$ & $\begin{array}{l}32.2 \\
37.1\end{array}$ & $\begin{array}{l}46.9 \\
28.7+\end{array}$ & $\begin{array}{l}49.2 \\
57.1\end{array}$ & $\begin{array}{l}55.7 \\
61.3+\end{array}$ & $\begin{array}{l}55.3 \\
66.4+\end{array}$ & $\begin{array}{l}55.7 \\
62.3\end{array}$ & $\begin{array}{l}51.2 \\
56.9\end{array}$ & $\begin{array}{l}35.8 \\
38.8\end{array}$ \\
\hline $11-16$ years old & $\begin{array}{l}9 \\
0\end{array}$ & $\begin{array}{l}27.3 \\
18.9\end{array}$ & $\begin{array}{l}28.8 \\
30.0\end{array}$ & $\begin{array}{l}57.3 \\
40.9\end{array}$ & $\begin{array}{l}53.3 \\
40.0\end{array}$ & $\begin{array}{l}54.7 \\
46.7\end{array}$ & $\begin{array}{l}59.2 \\
45.0+\end{array}$ & $\begin{array}{l}55.7 \\
40.0+\end{array}$ & $\begin{array}{l}50.0 \\
35.0+\end{array}$ & $\begin{array}{l}50.0 \\
28.3+\end{array}$ \\
\hline \multirow[t]{2}{*}{ Young ådults } & \& & $12.5++$ & 22.9 & 44.7 & $\begin{array}{c}64.4 \\
++\end{array}$ & $\begin{array}{l}80.1++ \\
++\end{array}$ & 57.6 & 53.5 & 53.6 & $38.2^{\circ}$ \\
\hline & $\delta$ & 18.7 & 22.3 & 39.6 & 39.0 & 50.8 & 56.1 & $62.3+$ & $62.5++$ & 35.8 \\
\hline
\end{tabular}

+ statistical significance of $\mathrm{p} 0.05$

+ statistical significance of $p 0.005$

asterisk behind the number: significant difference to the younger group

asterisk between numbers: significant difference between sexes 

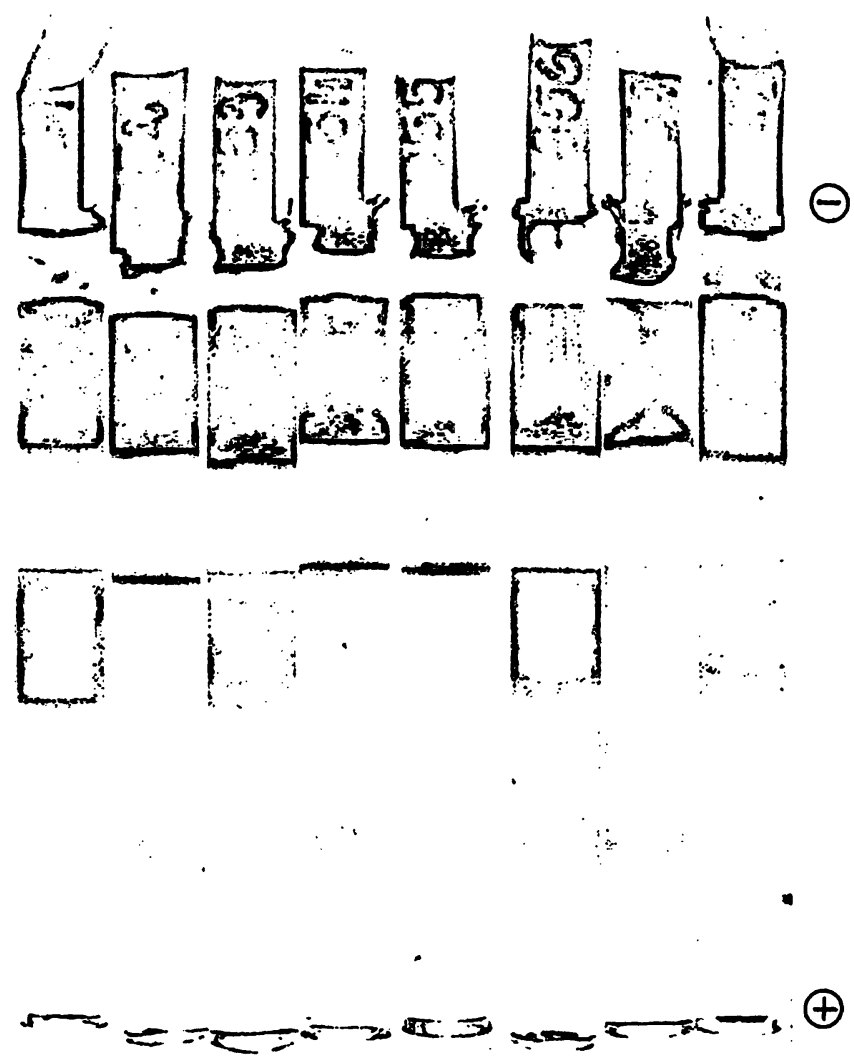

Fig. 4. A batch of columns with sera of patients on different days of acute hepatitis. Compare with fig. 1 and 3. Note the absence of the most of the SMDL in columns Nos. 1954, 1955, 1957.

fractions disappeared temporary, except $f_{12}$ and the largest subfractions, $f_{1}, f_{2}$ and $f_{3}$, which increased significantly. Our experiments on animals confirmed the constancy and high significance of these phenomena.

\section{Discussion}

The study described in this paper is a continuation of our earlier investigations on the dye-labeling of serum proteins $(11,12)$. In these studies, we showed the disappearance of an ICG-labeled protein (possibly an alphalipoprotein) in some liver diseases. We required an alternative, but a simple method, for the measurement of the amount of this protein in the serum of patients suffering from liver diseases. We did not want to investigate all biochemical and physical properties of HDL, SMDL or alpha-lipoproteins. A diagnostic method was required with satisfactory precision and reproducibility, easy to perform and standardise. We therefore chose the simplest and most standardisable method using the prestaining of lipoproteins (9). Poststaining probably carries a smaller risk of artefacts, but it is much more complicated and difficult to standardise; our experience with poststained paper and celluloseacetate electrophoresis of proteins (13) shows that there are many problems connected with the standardisation of this method.

The inhomogeneity of the lipoproteins from $\alpha$-region (or $\mathrm{HDL}$ ), when separated by polyacrylamide gel electrophoresis, was observed by Narayan et al. (3) in 1965. These authors used the HDL fraction obtained by ultracentrifugation. Dangerfield \& Pratt (4) fractionated whole serum and observed a fast migrating group of lipoproteins that penetrated $6.5 \%$ polyacrylamide gel and separated into several subfractions. They defined the lipoproteins of this group as "small molecular diameter lipoproteins" (SMDL) in contrast to the slow migrating ones, which did not penetrate more concentrated gel and which were defined as "large molecular diameter lipoproteins" (LMDL).

We used a different concentration of gel from that of Dangerfield \& Pratt ( $75 \mathrm{~g} / \mathrm{l}$ instead of $65 \mathrm{~g} / \mathrm{l})$, but we have retained the nomenclature SMDL. The difference was not significant; after leaving the spacer gel, the lipoproteins differentiated themselves very early into 2 groups: a fast moving one penetrating separation gel II and the other, slower group, remaining in separation gel I. There were no lipoproteins, between these 2 groups, so it seemed that the name SMDL is equally appropriate for lipoproteins penetrating $6.5 \%$ or $7.5 \%$ gels.

The inhomogeneity of the fast migrating lipoproteins was also observed by other authors $(5,7,8)$. Anderson et al. (8) found, by ultracentrifugation, 3 major components of HDL; Utermann (5) identified, by gel electrophoresis, 4 subfractions in this group, but the author obtained satisfactory separations only after the addition of laurinic acid to the serum.

The subfractions of SMDL appeared in the form of "discs" or "zonal" fractions. This is probably indicative of smaller or greater inhomogeneity of the lipoprotein molecules in the particular subfractions.

Particular subfractions appeared in investigated sera with different frequency. This has also been observed by other authors $(4,5)$. Possible causes are genetic factors, physiological oscillation of the amount of some proteins etc.

For clinical purposes it is necessary to have quantitative results. Some authors $(2,8)$ have reported quantitative data based on centrifugal analysis. This method could not be used for clinical purposes because of its complexity. Dangerfield \& Pratt observed changes in the amount of particular subfractions of SMDL, but the results were not strictly quantified. Utermann also found qualitatively different patterns of SMDL in various persons; he also ascertained quantitative differences, but did not give any values for the disc-electrophoretic subfractions. The main aim of our experiments was to obtain a really 
quantitative method for the objective statement of relative small differences of SMDL subfraction levels for clinical purposes. We thus developed the above described method, which enables us to state numeral differences between particular persons. On the other hand, the pattern of SMDL subfractions in any one individual is relatively stable over a period of a few days (this was not reported by other authors). It was also possible to show differences depending on sex, age and pathology.

In contrast to individual differences between particular persons these differences were sometimes very charac-

\section{References}

1. Burstein, M. (1961) Bull. Schweiz. Akad. Med. Wiss. 17, 92-110.

2. Barclay, M., Trebus-Kekish, O., Skipski, V. P. \& Barclay, R. K. (1965) Clin. Chim. Acta 11, 389-394.

3. Narayan, K. A., Narayan, S. \& Kumerow, F: A. (1965) Nature 205, 246-248.

4. Dangerfield, W. G. \& Pratt, J. J. (1970) Clin. Chim. Acta 30, 273-278.

5. Utermann, G. (1972) Clin. Chim. Acta 36, 521-529.

6. Feliste, R., Dousset, N. \& Douste-Blazy, L. (1973) Clin. Chim. Acta 47, 329-333. teristic and distinct e.g. women in comparison with girls, or in the umbilical cord blood when compared with blood of small children. This confirms the practical utility of our method. The differences connected with pathology were sometimes even more distinct, e.g. by some gynecological disturbances or in some liver diseases, which indicates some of the fields of clinical medicine where this method could be used in the diagnosis and/or understanding of the physiopathological mechanism in some diseases.

7. MaçKenzie, S. L., Sundaram, G. S. \& Shodi, H. S. (1973) Clin. Chim. Acta 47, 329-333.

8. Anderson, D. W., Nichols, A. V., Forte, T. M. \& Lindgren, F. T. (1977) Biochim. Biophys. Acta 493, 55-68.

9. Ressler, N., Springgate, R. \& Kaufman, J. (1961) J. Chromatog. 6, 409-415.

10. Wollenweber, J. \& Kahlke, W. (1970) Clin. Chim. Acta 29, $411-420$

11. Janecki, J. \& Krawczynski, J. (1970) Clin. Chim. Acta 16, 1008-1011.

12. Janecki, J. (1973) Zbl. Pharm. 112, 357-366.

13. Hertel, Z. \& Janecki, J. (1976) Diagn. Lab. XII, 81-87.

Doc. Dr. Jerzy Janecki Leiter der Abteilung für Labor-Diagnostik Institute of Pediatrics Medical Academy ul. Litewska 14/16 PL-00-576 Warszawa 